\title{
Factors in the Development of Entrepreneurial Competencies
}

\author{
Anastasiya Pesha ${ }^{1, *}$ \\ ${ }^{1}$ Ural State University of economics, Department of labour economics and HR management, 8 Marta 62, 620144 Yekaterinburg, \\ Russia
}

\begin{abstract}
Entrepreneurship is one of the main factors of economic growth, which ensures sustainable development of countries. Educational institutions and corporate universities develop programmes to develop entrepreneurial competencies of students and employees. Companies are introducing new functional divisions whose activities are related to revealing internal entrepreneurial competencies. This paper provides a systematic review of research in order to analyse the factors affecting the development of student and employee entrepreneurial competencies. Analysis of global, national, intra-organizational and personal factors in the development of entrepreneurial competencies makes it possible to form the most flexible and risk-resistant system of teaching entrepreneurship in universities and organizations.
\end{abstract}

Keywords: competencies; entrepreneurial competencies; intrapreneurship; innovation; factors; sustainable development; competitiveness

\section{Introduction}

Use The economic situation, large-scale technological changes, globalization trends and the competitive environment, observed as the phenomena of the digital economy, are reflected in the entrepreneurial activity of the population. Entrepreneurs contribute to increasing the economic well-being of people and innovative social development [1]. The development of entrepreneurship has a positive effect on reducing the unemployment rate by creating new jobs, thus ensuring the economic development as well as the social stability of society [2]. To ensure stability and development, companies are constantly working to improve their business models, products and services provided. One of the tools for this improvement is the development of intrapreneurship. As a result of the activities of internal entrepreneurs, new products and services are introduced, new corporate enterprises are initiated, new markets and business development horizons are opening [3]. Hypotheses about a positive correlation between the effectiveness of intrapreneurship, the development of entrepreneurial competencies, and business growth are obtained empirically [4].

What is currently happening with the indicators of entrepreneurial activity? The COVID-19 pandemic has affected the economies of countries and entrepreneurs' activities. Some entrepreneurs were forced to close their businesses, revise their activities in new conditions, and for some people, the current situation opened up new opportunities for the implementation of business ideas. According to the Global Entrepreneurship Monitor 2020-2021 (Global Entrepreneurship Monitor, GEM), compiled by Elam A.B., Brush C.G., Greene P.G., Baumer B., Dean M. and Heavlow R., in 2020, indicators of early-stage entrepreneurial activity fell by more than $25 \%$ in 9 out of 35 surveyed countries ( 4 of them in Europe [5, p. 43]). At the same time, during the pandemic, the above indicator of entrepreneurial activity increased by more than $25 \%$ in 4 countries - Oman, Egypt, Panama and Colombia [5]. It should be noted that the indicators of entrepreneurial activity in various countries presented in the study are ambiguous; therefore, it is impossible to say that the COVID-19 $\mathrm{p}$ has significantly affected them. This pandemic was an extreme event for which countries had not been prepared.

The scientific community becomes increasingly interested in the development of entrepreneurial competencies, the development of intrapreneurship, arguing that the need to study entrepreneurial competencies from the point of view of their "potential" (opportunities for their application in the field of entrepreneurship), and not only "capital" (the availability of special education and entrepreneurial experience) is human $[4,6]$. A large number of studies by scientists in this area are aimed at studying the possibilities of higher education in the formation of entrepreneurial competencies $[1,7]$. The factors of entrepreneurial competencies' development were studied by Palos-Sanchez P.R., Baena-Luna P., Pena A.C. [8]. Factor analysis of domestic entrepreneurship was performed by scholars such as Bouchard. V, Basso O., Menzel H. C., Aaltio I., Ulijn J. M. and others [9, 10].

The objective of this paper is the analysis of global, national, intra-organizational and personal factors that influence the formation of entrepreneurial competencies and the development of intrapreneurship.

\footnotetext{
* Corresponding author: myrabota2011@gmail.com
} 
Among the research questions formulated in this paper, there is highlighted the analysis of sources representing different approaches to the interpretation of intrapreneurship; research on the main differences between entrepreneurship and intrapreneurship; classifications of entrepreneurial competencies, as well as factors of different levels of influence on the development of entrepreneurial competencies of people and intrapreneurship in companies.

\section{Methodology}

Literature review was chosen as the main research method, as it best meets the objective and research questions. The literature review included the following stages: formulation of research questions, review and selection of relevant studies taking into account the selected definitions, analysis of the results.

Relevant papers were selected from the international abstract databases Web of Science and Google Scholar, search definition "entrepreneurial competence". The search included papers published from the year 2010 to the present, except for some papers most popular in the scientific community which deal with the topic of research with the highest citation rates. The year 2010 was selected since at this time, a sharp increase in the interest of the scientific community in the problems of entrepreneurship factors and the development of entrepreneurial competencies was recorded (the number of publications per year in Google Scholar $>200$, more than $60 \%$ of publications deal with the factors of entrepreneurship development / entrepreneurial competencies). Selection criteria for publications, in addition to the key search definition, were as follows:

1. Studying the factors / conditions for the development of entrepreneurial competencies;

2. Included analysis of entrepreneurship and intrapreneurship characteristics.

3. The empirical component as the basis for the research results presented in the papers.

On the basis of the selected criteria, more than 50 papers that meet these criteria were studied; the most significant ones are included in References.

\section{Results and Discussion}

\subsection{Features of intrapreneurship and the main approaches to its understanding}

There are several definitions of the concepts of "intrapreneur" and "intrapreneurship". Some scholars define intrapreneurship as a synonym for the concept of "corporate entrepreneurship" [11], while others describe the existence of certain differences between these two phenomena, pointing out that in corporate entrepreneurship, the initiation of entrepreneurial activity starts from the top down, while in the case of intrapreneurship, it is from the bottom up [3]. There are many scientists who believe that intrapreneurship is a sub-area of entrepreneurship [12]; others define it as "innovative practice within an organization, with the help of which employees take on new types of business activities and use various opportunities" [13, p. 813]. Nevertheless, all definitions of "intrapreneurship" have certain features in common: the manifestation of initiative and the introduction of innovations (entrepreneurial behaviour), the implementation of ideas within the framework of an existing company and for its benefit. We agree most with the concept of intrapreneurship formulated by Vargas-Halabí T., Mora-Esquivel R., Siles B., who claim that "intrapreneurship is a process in which an individual or group of individuals, within the framework of an existing organization, identify, pursue, and encourage innovative opportunities and create a new organization, renewing the organization or introducing product and process innovations" [14, p. 89]. Based on the existing interpretations, the most complete definition of the concept of an internal entrepreneur was formulated, which we adhere to in our research: An intrapreneur is an employee of an organization with an entrepreneurial mindset [15], capable of creating, identifying and using new opportunities to turn an idea into a profitable finished product [16] by actively taking risks and innovations [17]. In addition to entrepreneurial thinking, the following competencies are necessary for an intrapreneur: seizing opportunities; innovation; stimulating ideas; planning; risk management; resource management; maintaining relationships; building interaction with others [14].

Analysis of existing approaches shows there are two levels of manifestation of intrapreneurship - organizational and personal. The organizational level is associated with the creation of conditions and entrepreneurial orientation, while the personal level is connected with the entrepreneurial behaviour and competencies of employees when they are involved in intrapreneurship [3]. From our point of view, both of these levels deserve equal attention. The creation of intraorganizational conditions is one of the main factors in identifying entrepreneurial competencies of a specialist. At the same time, it is necessary to influence personal attitudes, intention and development of entrepreneurial competencies not only within the organization, by creating the conditions indicated above, but even in the process of professional training and personal development of future specialists at universities. The factors of development of entrepreneurial competencies are discussed in more detail in Chapter 3.2.

Summing up the results of this chapter, it should be noted that scientists distinguish a number of differences between intrapreneurship and entrepreneurship. Having analysed various points of view, the key ones were formulated as follows: 
- entrepreneurial efforts and activities are carried out within a company with an established policy and culture;

- entrepreneurial activities are carried out as a result of interconnected entrepreneurial activities of several participants;

- entrepreneurial activities can be implemented at different organizational levels;

- the organization assumes all risks associated with the implementation of intrapreneurs' initiatives;

- intrapreneur's flexibility in decision-making and achieving a business goal is limited;

- the decision-making process in intrapreneurship is lengthy, conditioned by the approval of the company's management;

- the ability of the intrapreneur to use the resources of the organization to develop the idea;

- intrapreneurs do not think about the financial component of their initiative, they are focused on drawing up innovative and feasible plans;

- intrapreneurs' activities have organizational security;

- in case of failure to implement entrepreneurial activity, intrapreneurs still receive remuneration from the company.

We believe that when implementing the policy for the development of intrapreneurship in the company or for the formation of entrepreneurial competencies of university students, the above differences shall be taken into account, since motivation, self-confidence and, finally, the implementation of various kinds of business initiatives of employees and alumni can depend on this.

\subsection{Key factors in the development of entrepreneurial competencies}

Intrapreneurship is very multifaceted and is influenced by numerous factors, some of which are of an objective socioeconomic nature. The degree of influence of this type of factors can vary from country to country due to specific conditions of economic development and cultural characteristics. These factors are presented in this article in two groups x - global factors and national factors. of the study by Kim Y. T., \& Heo C. M. analyses the significant influence of the factor of social values on the formation of entrepreneurial competencies and the implementation of entrepreneurial intentions [18].

In addition to global and national factors of influence, we identified the meso-level - the level of education and educational environment, which has a significant impact on the development of not only the corresponding range of competencies, but also on the identification of entrepreneurial intentions. The impact of teaching entrepreneurship competencies at universities on the implementation of entrepreneurial intentions has been addressed in many studies published in the last 2 years. As an example, there can be mentioned the article by Lv Y. et al., who conducted a survey including more than 5000 undergraduates in China. The results show that the development of entrepreneurial competencies plays an intermediary role for the practice of entrepreneurship and entrepreneurial intention [1].

The globalization of economic processes, strong competition and high demand for innovation complicates the organizational environment, changing the approach of companies to human resources and the use of their talents. Companies that are focused on attracting employees to innovative internal corporate behaviour must create an organizational climate that would motivate the employees to entrepreneurial initiatives. The internal entrepreneurial climate is characterized by "a positive correlation between management support, remuneration system and employee autonomy" and affects the innovativeness of employees and the transformation of ideas into real goods and services of companies [19]. The concept of "entrepreneurial climate" includes the style of leadership and support from management. The table below thus does not present these factors separately, as highlighted by a number of authors [10]. In addition to the entrepreneurial climate, the key intra-organizational factors for the development of entrepreneurial competencies represent new ways of working (NWW), internal competitions of ideas for the development of innovative culture in the company, which allow employees to gain recognition and be aware of their importance for the company, and the creation of conditions for personnel initiatives, as research shows, has significant impact on the development of domestic entrepreneurship [6]. The authors also pay great attention to the development of communications and relationship of trus within the team as a factor in the innovative behaviour of employees [20].

A review of factors in the development of entrepreneurial competencies will be incomplete if the key group of them personal factors - are not considered. This group of factors has the greatest impact on the development of competencies and on the formation of entrepreneurial intentions [2]. First of all, it is necessary to mention motivation as a driving factor of personal development. In addition to motivation, studies conducted show the high importance of extraversion, openness and awareness for the development of entrepreneurial competencies [21]. Moreover, Schmitt-Rodermund E. empirically investigated and confirmed the existence of a high correlation of these factors with the level of student interest in entrepreneurship. Personal development and the environment in which the personality, worldview and personal attitudes are formed play a significant role in the development of entrepreneurial competencies and intentions. Based on the results of our research, we have added parenting to personality factors, meant as outcome, not process. 
Table 1. Factors in development of entrepreneurial competencies

\begin{tabular}{|c|c|c|}
\hline $\begin{array}{l}\text { Group of } \\
\text { factors }\end{array}$ & Factors & Authors \\
\hline \multirow{2}{*}{ Global } & Digitization & Morris T. H., \& König P. D., 2020 [22] \\
\hline & Globalization & Benevolo C., Penco L. and Torre T., 2021 [23] \\
\hline \multirow{4}{*}{ National } & social values & Kim Y. T., \& Heo C. M. $2021[23]$ \\
\hline & $\begin{array}{l}\text { state regulation of entrepreneurship and } \\
\text { regional policy }\end{array}$ & Li C. et al., 2020 [24]; Motoyama, Y. and K. Knowlton, 2016 [25]. \\
\hline & market conditions and taxation & Lovkova E., et al., 2018 [26]. \\
\hline & infrastructure development & Lovkova E., et al., 2018 [26]. \\
\hline \multirow{3}{*}{$\begin{array}{l}\text { Education } \\
\text { al }\end{array}$} & higher education in entrepreneurship & Iglesias-Sánchez P. P., et al., 2021 [27]; Lv Y., Chen Y., 2021 [1]. \\
\hline & entrepreneurship courses, business education & Palos-Sanchez P.R., et al.,2019 [8]. \\
\hline & $\begin{array}{l}\text { accelerators, hackathons and business } \\
\text { incubators }\end{array}$ & $\begin{array}{c}\text { Iglesias-Sánchez P. P., } 2019 \text { [27]; Li C. et al., 2020; Pesha A., } \\
\text { Shavrovskaya M., \& Caha Z.,2021 [7]. }\end{array}$ \\
\hline \multirow{5}{*}{$\begin{array}{l}\text { Intra- } \\
\text { organizati } \\
\quad \text { onal }\end{array}$} & Motivation & Menzel et al. 2007 [10]; Park S. H., et al., 2014 [20]. \\
\hline & business climate and development strategy & $\begin{array}{c}\text { Gerards R., van Wetten S., \& van Sambeek C., } 2020 \text { [6]; Menzel et } \\
\text { al. } 2007 \text { [10]; Park, } 2014 \text { [22]; Poduška Z. и др.[19], 2020; Zahra } \\
\text { S. A., } 1991 \text { [11] }\end{array}$ \\
\hline & corporate sustainability & Hyuk K. H., \& Park W., 2019 [2]. \\
\hline & NWW & Gerards R., van Wetten S., \& van Sambeek C., 2020 [6]. \\
\hline & $\begin{array}{l}\text { organizational capabilities (information, } \\
\text { finance, working hours) }\end{array}$ & Poduška Z. и др., 2020 [19]. \\
\hline \multirow{7}{*}{ Personal } & motivation and intentions & $\begin{array}{l}\text { Hyuk K. H., \& Park W. } 2019 \text { [2]; Lv Y., ChenY., et al, } 2021 \text { [1]; } \\
\text { Schmitt-Rodermund E., } 2004 \text { [21]. }\end{array}$ \\
\hline & Awareness & \multirow[t]{3}{*}{ Schmitt-Rodermund E., 2004 [21]. } \\
\hline & Openness & \\
\hline & Extraversion & \\
\hline & upbringing and origin & Schmitt-Rodermund E., 2004 [21]; Stewart W., Roth P., 2007 [28]. \\
\hline & Values & Stewart W., Roth P., 2007 [28]. \\
\hline & gender, age, education, experience & Parker S. C., 2011 [12]; Pawitan G. et al., 2018 [29] \\
\hline
\end{tabular}

Source: Author.

\section{Conclusion}

The current economic situation and technological progress, business globalization and global socio-political turbulence have an impact on the development of entrepreneurial competencies and the formation of entrepreneurial intentions both outside and inside companies. Business owners are looking for new opportunities to maintain the stable development, efficiency and competition of organizations. In view of the relevance of this topic, this paper identifies the main approaches to understanding and distinguishing entrepreneurship from intrapreneurship, which, although having many forms, have the following in common: the initiation of entrepreneurial activity within the company (both upward and downward), the employees with the appropriate set of competencies and motivation, and the use of the organization's resources for the implementation of such initiatives.

Based on the content analysis of publications dealing with the same topic, the main differences between the phenomena of entrepreneurship and intrapreneurship are identified in the risk management that the organization undertakes for the implementation of intrapreneurial initiatives and in the motivation of intrapreneurs, which differs from the motivation of entrepreneurs interested in self-realization.

Within the paper, several groups of factors for the development of entrepreneurial competencies are identified (see Table 1). The views of scientists to the issues of factors differ significantly; nevertheless, we believe that all the selected factors need to be equally taken into account, since only a holistic approach to the development of entrepreneurial competencies can lead to the expected growth in the indicators of entrepreneurial activity of the population of the countries.

Due to the influence of macro factors, a large number of risks arise in the manifestation of entrepreneurial initiatives and the start-up of new organizations. We agree with Iglesias-Sánchez P. P., et al., 2021; Lv Y., Chen Y., 2021. and other authors who highlight the unambiguous importance of educational factors for the development of entrepreneurial competencies and entrepreneurial intentions [1,28]. The development of educational infrastructure and the introduction of courses and methods for teaching entrepreneurship in various areas of student training will become an additional driver for the development of entrepreneurship and the economy of countries as a whole. Our analysis shows that the key factors in the manifestation of entrepreneurial initiatives and encouraging of employee entrepreneurial thinking include the creation of an entrepreneurial climate and organizational policy aimed at strategic business development. A large number of studies show the influence of various demographic factors on the development of entrepreneurial competencies and the formation of entrepreneurial intentions, for example, Parker S. C., 2011 [12]; Pawitan G. et al., 2018 [29]. At the same time, we believe that the analysis of the influence of these factors on this phenomenon requires deeper and more extensive 
research and should involve the analysis of demographic factors in parallel with the socio-economic and cultural characteristics of different regions and countries. As for other personal factors, we tend to agree the authors whose work is presented in the final analysis, and who claim that the main thing is the motivation and intention to develop competencies and start up their own business. At the same time, it should be noted that it is possible to influence the formation of a person's motivation and intentions in the field of entrepreneurship through the implementation of targeted educational programmes, as mentioned e.g. in the study by Lv, Y., Chen, Y., 2021 [1].

In our opinion, the future is in the increased attention paid to the education system in order to achieve intentional development of entrepreneurial competencies, which concerns not only specialized areas of training, but also the inclusion of relevant courses and disciplines in the Bachelor's and Master's degree programmes. This initiative will allow us to recognize entrepreneurial talents and create conditions for the implementation of student and graduate entrepreneurial intentions, which will have a positive impact on the indicators of entrepreneurial activity of young people.

Our analysis of the factors for the development of entrepreneurial competencies can be applied in strategic programmes in order to ensure the development of intrapreneurship within companies, as well as in further scientific research on the influence of external and internal factors on the development of student entrepreneurial competencies and intentions.

\section{Acknowledgment}

The reported study was funded by RFBR, project number 19-29-07435

\section{References}

1. Y. Lv, Y. Chen, Y. Sha, J. Wang, L. An, T. Chen, L. Huang. How Entrepreneurship Education at Universities Influences Entrepreneurial Intention: Mediating Effect Based on Entrepreneurial Competence. Frontiers in Psychology. 12 (2021)

2. K. H. Hyuk, W. Park. Impact of Entrepreneurial Business Start-up Motivation, Entrepreneurial Spirit, and Entrepreneurial Competence Characteristics on Start-up Companies' Sustainability: Focusing on the Mediating Effect of the Start-up Companies' Business Performance. Asia-Pacific Journal of Business Venturing and Entrepreneurship. 14(3), 59-71 (2019)

3. J. C. Rigtering, G. U. Weitzel, K. K. Muehlfeld. Increasing quantity without compromising quality: How managerial framing affects intrapreneurship. Journal of Business Venturing. 34(2), 224-241 (2019)

4. T. Lans, M. Van Galen, J. Verstegen, H. Biemans, M. Mulder. Searching for Entrepreneurs among Small Business Owner-Managers'. Proceedings of the ECER. 1-22 (2010)

5. A. B. Elam, C. G. Brush, P. G. Greene, B. Baumer, M. Dean, R. Heavlow. Global Entrepreneurship Monitor. 2020/2021 Global Report [online]. Published by the Global Entrepreneurship Research Association, London Business School, Regents Park, London NW1 4SA, UK, 2021. Available at: https://www.gemconsortium.org/report/gem-20202021-global-report (2021)

6. R. Gerards, S. van Wetten, C. van Sambeek. New ways of working and intrapreneurial behaviour: the mediating role of transformational leadership and social interaction. Review of Managerial Science. 1-36 (2020)

7. A. Pesha, M. Shavrovskaya, Z. Caha. Comparative Analysis of the Level of Development of Entrepreneurial Competencies among Students in Russia and the Czech Republic. SHS Web of Conferences. 90(1):02007 (2021)

8. P. R. Palos-Sanchez, P. Baena-Luna, A. C. Pena. Analysis of educational competences to evaluate entrepreneurial people. Interciencia. 44(5), 291-297 (2019)

9. V. Bouchard, O. Basso. Exploring the links between entrepreneurial orientation and intrapreneurship in SMEs. Journal of Small Business and Enterprise Development. 18(2), 219-231 (2011)

10. H. C. Menzel, I. Aaltio, Ulijn J. M. On the way to creativity: Engineers as intrapreneurs in organizations. Technovation. 27(12), 732-743 (2007)

11. S. A. Zahra. Predictors and financial outcomes of corporate entrepreneurship: An exploratory study. Journal of Business Venturing, 6(4), 259-285 (1991)

12. Parker S. C. Intrapreneurship or entrepreneurship? Journal of business venturing. 26(1), 19-34 (2011)

13. B. Baruah, A. Ward. Metamorphosis of intrapreneurship as an effective organizational strategy. International Entrepreneurship and Management Journal. 11(4), 811-822 (2015)

14. T. Vargas-Halabí, R. Mora-Esquivel, B. Siles. Intrapreneurial competencies: development and validation of a measurement scale. European Journal of Management and Business Economics. 26 (1), 86-111 (2017) 
15. G. Pinchot. III. Intrapreneuring: Why you don't have to leave the corporation to become an entrepreneur. University of Illinois at Urbana-Champaign's Academy for Entrepreneurial Leadership Historical Research Reference in Entrepreneurship (1985)

16. H. Ma, T.Q. Liu, R. Karri. Internal corporate venturing: intrapreneurs, institutions, and initiatives. Organizational Dynamics. 45(2), 114-123 (2016)

17. J. Augusto Felício, R. Rodrigues, V. R. Caldeirinha. The effect of intrapreneurship on corporate performance. Management Decision. 50(10), 1717-1738 (2012)

18. Y. T. Kim, C. M. Heo. The Influence of Senior Entrepreneurship Competency and Start-up Support Policy on Entrepreneurship Intention: Focusing on the Moderating Effect of Mentoring. Asia-Pacific Journal of Business Venturing and Entrepreneurship. 16(2), 109-121 (2021)

19. Z. Poduška, J. Nedeljković, D. Nonić, T. Ratknić, M. Ratknić, I. Živojinović. Intrapreneurial climate as momentum for fostering employee innovativeness in public forest enterprises. Forest Policy and Economics. 119, 102281 (2020)

20. S. H. Park, J. N. Kim, A. Krishna. Bottom-up building of an innovative organization: Motivating employee intrapreneurship and scouting and their strategic value. Management Communication Quarterly. 28(4), 531-560 (2014)

21. E. Schmitt-Rodermund. Pathways to successful entrepreneurship: Parenting, personality, early entrepreneurial competence, and interests. Journal of vocational behavior. 65(3), 498-518 (2004)

22. T. H. Morris, P. D. König. Self-directed experiential learning to meet ever-changing entrepreneurship demands. Education+ Training. 63(1), 23-49 (2021)

23. C. Benevolo, L. Penco, T. Torre. Entrepreneurial decision-making for global strategies: a "heart-head" approach. Management Decision. 59(5), 1132-1157 (2021)

24. C. Li, N. Ahmed, S. A. Qalati, A. Khan, S. Naz. Role of business incubators as a tool for entrepreneurship development: the mediating and moderating role of business start-up and government regulations. Sustainability. 12(5), $1822(2020)$

25. Y. Motoyama, K. Knowlton. From Resource Munificence to Ecosystem Integration: The Case of Government Sponsorship in St. Louis. Entrepreneurship \& Regional Development. 28(5-6), 448-470 (2016)

26. E. Lovkova, T. Kashicina, D. Savenkov, A. Kuzmina. Key vectors and concerns of small-sized entrepreneurship development in the Russian Federation. Challenging the Status Quo in Management and Economics. 19-25 (2018)

27. P. P. Iglesias-Sánchez, C. Jambrino-Maldonado, C. de las Heras-Pedrosa. Training entrepreneurial competences with open innovation paradigm in higher education. Sustainability. 11(17), 4689 (2019)

28. W. Stewart, P. Roth. A meta-analysis of achievement motivation differences between entrepreneurs and managers. Journal of Small Business Management. 45(4), 401-421 (2007)

29. G. Pawitan, M. Widyarini, C. B. Nawangpalupi. Moderating effect of demographic factors and entrepreneurial phase on the relationship between entrepreneurial competencies and innovation of ASEAN entrepreneurs. Pertanika Journal of Social Science and Humanities. 26, 151-166 (2018) 